\title{
NEST CHARACTERISTICS OF THE EASTERN ROCK NUTHATCH (SITTA TEPHRONOTA) IN SOUTHWESTERN IRAN
}

\author{
Arya Shafaeipour ${ }^{1 *}$, Behzad Fathinia ${ }^{1}$ and Jerzy Michalczuk ${ }^{2}$ \\ ${ }^{1}$ Department of Biology, University of Yasouj, Yasouj, Iran \\ E-mails: shafaei@yu.ac.ir,https://orcid.org/0000-0002-4267-536X \\ bfathinia@gmail.com, https://orcid.org/0000-0001-5752-9288 \\ ${ }^{2}$ Department of Nature Protection and Landscape Ecology, University of Rzeszów \\ Zelwerowicza 4, 35-601 Rzeszów, Poland \\ E-mail: jurmich@univ.rzeszow.pl, https://orcid.org/0000-0001-9311-7731
}

In the springs of 2015-2017, the population size and nest characteristics of the Eastern Rock Nuthatch (Sitta tephronota) were investigated. The study was conducted in a 400 hectare area of the mountainous region of southwestern Iran. In 2016, the population of the Eastern Rock Nuthatch was estimated at 33 pairs and its density was 8.25 breeding pairs per 100 ha of the study area. During the study, 45 nuthatch nests were investigated, of which 15 (33\%) were found in cliffs and 28 (62\%) were located in tree holes; $2 \%$ were built in house and bridge walls. The height of the nest was $214.3 \pm 112.3 \mathrm{~cm}$ above ground level. The mean of the horizontal and vertical depths of the nest chambers in trees was $17.8 \pm 3.7$ and $12.6 \pm 3.2$ $\mathrm{cm}$ respectively, and statistically differed from those in rocky nests (respectively $23.9 \pm 5.5$ and $10.8 \pm 4.6 \mathrm{~cm})$. However, chamber volumes did not statistically differ between these two nest type categories. The inner entrance areas of rocky nests were significantly smaller than those located in tree holes (respectively $11.1 \pm 2.3$ and $15.3 \pm 5.5 \mathrm{~cm}^{2}$ ). Our findings suggest that differences in nest characteristics may be an adaptation of the Eastern Rock Nuthatch to predation.

Key words: Eastern Rock Nuthatch, secondary hole-nesters, nest-cavity characteristics, mountains, rocky habitats, forests, Iran.

\section{INTRODUCTION}

The nuthatch family (Sittidae) includes over 20 species occurring mainly in Eurasia and North America (Harrap 1996, Matthysen 1998, Cramp \& Snow 2000, Pasqued et al. 2014, Harrap 2019). A few endemic species, e.g. the Algerian Nuthatch Sitta ledanti inhabit northern Africa (Moulaï et al. 2017), and some occur on islands, e.g. the Corsican Nuthatch Sitta whiteheadi (THibault et al. 2011) or Krüper's Nuthatch Sitta krueperi (Albayrak \& ErdoĞAn 2018). As cavity nesters, nuthatch species commonly nest in tree holes made by woodpecker (Picidae) species (WesoŁowski 1989, WesoŁowski \& StawarCzyk 1991, Pravosudov 1993, Harrap 1996, Matthysen 1998, Cramp \& Snow 2000, WesoŁowski \& Rowiński 2004). Nuthatches very rarely excavate cavities themselves or use nest boxes (Löhrl 1987, Matthysen 1998, AlbayraK \& ErdoĞan 2005, Maicas et al. 2012). Some species, like the Western Rock Nut- 
hatch Sitta neumayer and Eastern Rock Nuthatch Sitta tephronota, build nests in cavities in rocks or walls (Harrap 1996, Matthysen 1998, Cramp \& Snow 2000, HARRAP 2019).

The ecology of widespread nuthatch species, e.g. the Eurasian Nuthatch Sitta europea (WesoŁowski 1989, WesoŁowski \& Rowiński 2004, GonZÁlezVARO et al. 2008), is relatively well-known. Recent studies have enriched the knowledge of rare species, such as the Algerian Nuthatch (Moulaï et al. 2017) or Corsican Nuthatch (Thibault \& Villard 2005, Thibault et al. 2011). The ecology of North American species, such as the White-breasted Nuthatch Sitta carolinensis, Pygmy Nuthatch Sitta pygmaea, Red-breasted Nuthatch Sitta canadensis, has also been the subject of numerous studies (Brawn \& Balda 1988, Ghalambor \& Martin 2002, Norris \& Martin 2012). A few Asian species, e.g. Krüper's Nuthatch (Albayrak \& ErdoĞan 2005, Albayrak et al. 2010, 2011, AlbayraK \& ERdoĞAn 2018) have received scholarly attention. Until now, no detailed study was conducted on the nest cavity characteristics or breeding biology of the Eastern Rock Nuthatch. Only Naurouzi (2010) conducted a one-year study of this species in the Khoshyailagh protected area of northeastern Iran. This species is widespread in southwestern Asia (HARRAP 1996, Matthysen 1998). Its population occurs mainly in the Iranian Plateau, but its range includes other mountainous regions and neighbouring countries (ScotT et al. 1975, Harrap 1996, Matthysen 1998, Cramp \& Snow 2000, BirdLife International 2016). The species typically inhabits rocky areas, mountains, valleys, and low-density forests featuring an open canopy with sunlight and limited shade (VAurie 1950, ScotT et al. 1975). Nests of this species are similar to those of the Western Rock Nuthatch Sitta neumayer. The gourd-shaped structure of this bird's nests are made from mud and are located below rocks, bridges, and rarely in stone crevices (PORTER \& SPINALl 2010), however, in some areas it uses the old cavities of Picidae woodpeckers (Harrap 1996, Matthysen 1998, Cramp \& SNow 2000). Such different nest site preferences are still unclear, but they may play an important role in the breeding performance of birds (Zieliński 2011, Maziarz et al. 2016, Serrano-Davies et al. 2017), and finally, they could even influence the size of the bird population (e.g. RönKä et al. 2011). Some predictions suggest that the Eastern Rock Nuthatch may decrease in number or become extinct in some regions, e.g. in Iran. This species may decline along with its southern range and at lower elevations of mountain regions due to climate change (Menon et al. 2009). Knowledge about the habitat selection of this species can supplement information about its ecology, e.g. relating to its anti-predator strategies, and should provide crucial information needed for its monitoring and protection. Here we describe the nest site characteristics of the Eastern Rock Nuthatch in the temperate forest area of southwestern Iran. In the conducted study, we compared the nests of the Eastern Rock Nuthatch located in tree holes with those established in rock gaps. 


\section{MATERIAL AND METHODS}

The study area is a 400 hectare natural temperate forest at an elevation of 2,000-2,800 $\mathrm{m}$ a.s.l. located south of Yasuj city in southwestern Iran $\left(31^{\circ} 31^{\prime} \mathrm{N}, 51^{\circ} 09^{\prime} \mathrm{E}\right.$, Fig. 1). Annual rainfall averages $817 \mathrm{~mm}$ and the average annual temperature is $14^{\circ} \mathrm{C}$ (Meteorological Organization of the Islamic Republic of Iran 2017). The vegetation is represented by shrubs of the Astragalus, Acantholimon and Amygdalus genera. Tree species in this region include Mount Honeysuckle (Lonicera nummularifolia), Narrow-leafed Ash (Fraxinus angustifolia), Wild Pear (Pyrus glabra), Mount Atlas Mastic tree (Pistacia atlantica), Dotted Hawthorn (Crataegus puntica), and rarely, Persian Oak (Quercus brantii var. persica) on the forest edges and at lower elevations.

The study was conducted in the breeding season (from 30 March to 3 June) from 2015 to 2017. During the breeding season in 2016, four field surveys were conducted to assess the numbers of Eastern Rock Nuthatch (hereafter ERN) breeding pairs. A breeding territory was defined when the nest was found, or birds were confirmed in an area at least two times. Bird and nest searching was conducted along parallel lines by $2-4$ people (working $20 \mathrm{~m}$ away from each other) on foot, mainly in the afternoon for 6 hours a day. During the fieldwork, potential nest locations, such as dug out rocks, rock gaps, and old woodpecker nests, were investigated (Figs $2 \& 3$ ). Due to the size of the region and the presence of cliffs, accessing all possible nest sites in rocky areas and trees was impossible,

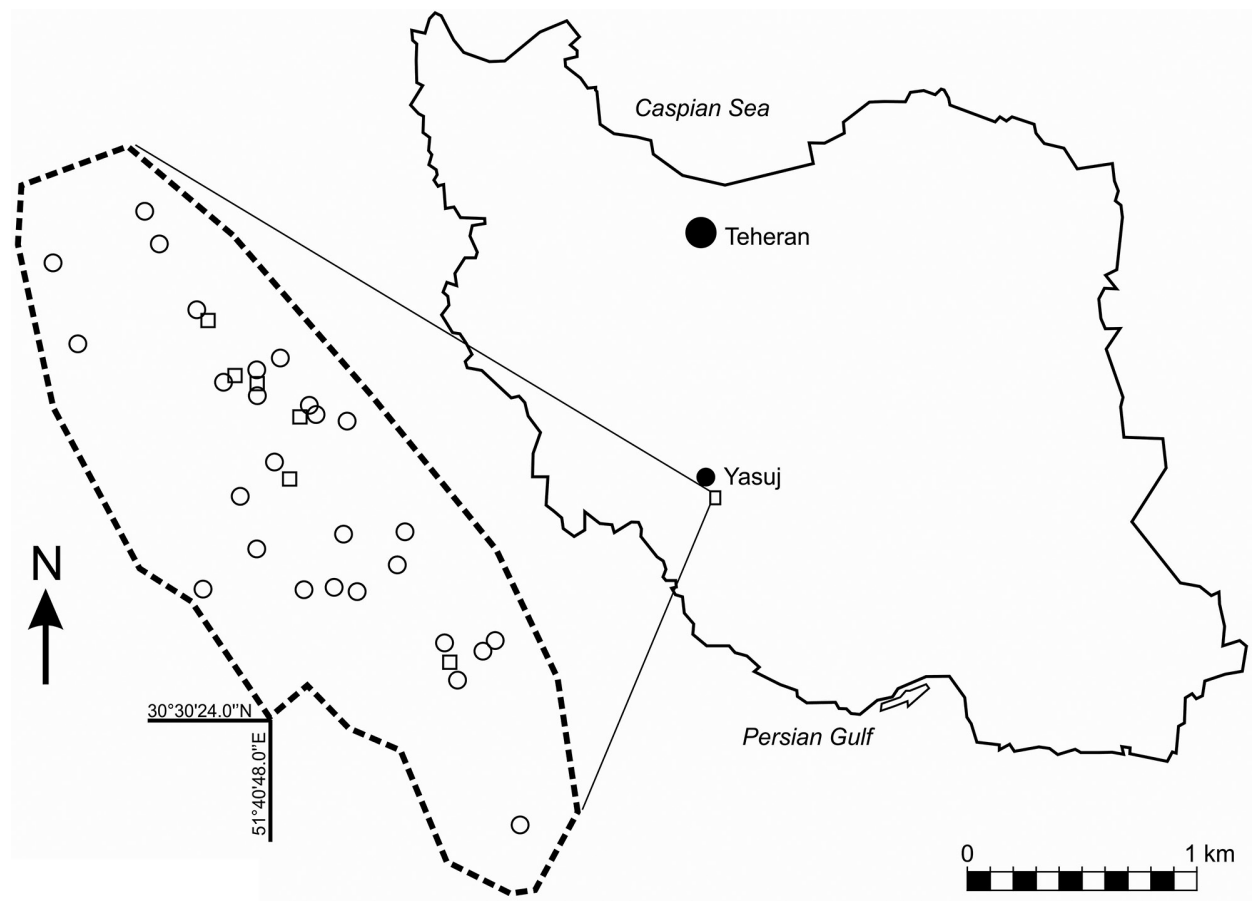

Fig. 1. Location of the study area in SW Iran and distribution of Eastern Rock Nuthatch breeding territories in 2016. Denotations: circle $=$ breeding territory with nest, square $=$ breeding territory without nest 
so we measured only those nests which could be accessed with ladders and tripods. We fixed the geographical positions and altitudes with a handheld GPS and calculated the distance to the nearest neighboring nests of all located nests. To assess nest parameters, all nests were divided into rock (including single nests located in a house wall and a bridge wall) and tree sites. After identifying the tree species, we measured the tree diameter at nest height $(\mathrm{DNH})$ and tree diameter at breast height $(\mathrm{DBH})$ with a measuring tape. We also measured the distance from the nest entrance to the ground and to the highest point of the cliff. During the study, we also made basic measurements of the nests, including the vertical and horizontal diameters inside the nest entrance, to the nearest millimeter with a digital caliper. We used a centimeter tape to measure the horizontal depth (horizontal diameter) of the chamber and its vertical depth (up to the nest material using flexible wire). The vertical slope of the nest site was evaluated with iLevel software 2.0 (www.jrsoftworx. com) installed on a mobile phone.

The orientation of the nest was assessed using the eight cardinal directions. To examine the frequency of nest entrance directions, the circular statistics method was used (LANDLER et al. 2018). The circular mean direction (mean angle) with a 95\% confidence interval was calculated. We tested whether the data followed a uniform distribution. A uniform distribution indicates that all directions are distributed randomly, and no mean direction occurs. To test whether there is statistical evidence of one-sidedness or directedness, we used the Rayleigh test (null hypothesis: the parent population is uniformly distributed; $\alpha=0.05$, BATSCHELET 1981). All circular statistics were performed using PAST 3 software (Hammer et al. 2001).

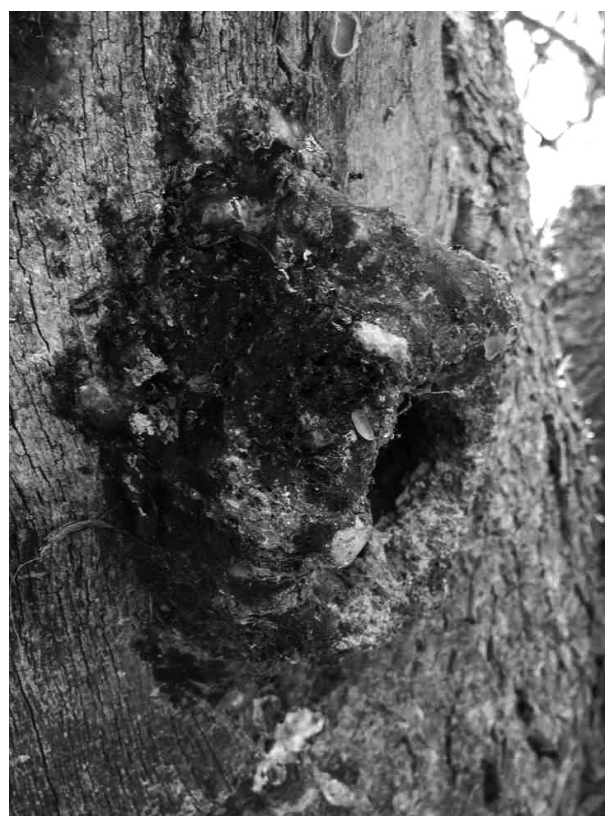

Fig. 2. Nest of the Eastern Rocky Nuthatch located in abandoned woodpecker tree hole (photo by A. Shafaeipour, Mahparwiz, Yasouj, 2015.05.05)

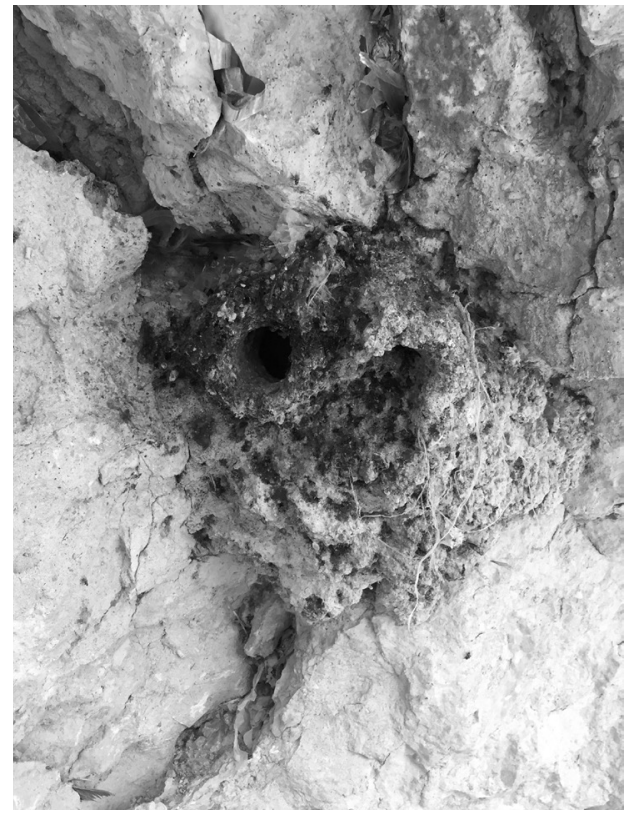

Fig. 3. Nest of the Eastern Rock Nuthatch made in rock gap (photo by A. SHAFAeIPOUR, Mahparwiz, Yasouj, 2015.05.29) 
The area of the entrance was calculated according to the formula: $\mathrm{A}=\pi \mathrm{ab}$, where $a$ and $b$ are the horizontal and vertical radius of the entrance.

The nest chamber volume was calculated using cylindrical approximation (Rемм et al. 2006): $V=\pi(c / 2) 2 d$, where $c$ is the chamber horizontal diameter, and $d$ is the chamber height (vertical depth).

In order to avoid disturbing the birds at their nests, we measured the nests' characteristics as quickly as possible or after the nestlings had fledged. For the analysis, we categorized nests in two groups according to their placement: 1 - nests in tree holes, and 2 - nests located in cliff walls, including in rocks and human-made structures, such as houses and walls. Out of 45 ERN nests, 28 nests were built in tree holes (including seven nests in 2015 and 21 in 2016), and 17 nests were located in cliff walls (including 6 nests in 2015, 6 nests in 2016, and 5 nests in 2017). Because the whole area of the study plot was 400 ha, the number of all breeding pairs noted in $2016(n=33)$ was divided by 4 to assess the density of the ERN population. In this way, the density of breeding pairs per 100 ha of the study area was calculated.

All data were analysed using Statistica 13.1 software. For data comparisons (tree and rock nests, or nests located in Narrow-leafed Ash and Mount Atlas Mastic trees), the MannWhitney U test was used. Additionally, we used Spearman's rank correlation coefficient to determine the interrelation between nest dimensions and nest height above the ground. All these statistical tests were performed using a significance of less than 0.05 . All results were reported as means \pm standard deviation $( \pm S D)$.

\section{RESULTS}

In 2016, the ERN population in the study area was estimated at 33 pairs (Fig. 1), and the density was 8.25 breeding pairs/100 ha. The average distance between the nearest neighboring nests was $138.1 \pm 72.8$ meters $(n=18)$ and ranged from 25 to 360 meters. The elevations of nest sites were recorded in the range of 2,013-2,833 $\mathrm{m}$ a.s.1. Birds built nests primarily in tree holes $(62 \%)$ excavated and abandoned by woodpeckers, and secondarily in rocky and wall sites (38\%, with single nests located in a house wall and a bridge wall, $n=45$ ). Most nests in the cliff or rocky sites were newly constructed by ERNs, except in two cases where birds used old nests $(12 \%, n=17)$. Among the trees, the Mount Atlas mastic was most frequently used by nesting birds $(71 \%, \mathrm{n}=28)$. Nuthatches also nested in ash trees (25\%), and a single nest was found in Persian oak (4\%). The average DBH of trees used for nesting was $43.7 \mathrm{~cm}$ (Table 1), and was very similar in the narrow-leafed ash and Mount Atlas mastic trees (Table 2). Likewise, no statistically significant differences were found between these two tree species for all other parameters (Table 2). Nuthatch nests were located from 0.38 up to $5.50 \mathrm{~m}$ high, but most $(44 \%, \mathrm{n}=45)$ were situated within the range of 1-2 $\mathrm{m}$ above ground level (Fig. 4). The height of the nest was about $48 \mathrm{~cm}$ higher in trees than in rocks, but these parameters did not differ statistically. The inner vertical and horizontal diameters, as well as the entrance area of the rocky nests, were smaller than those in tree nests (Table 1). Although the 


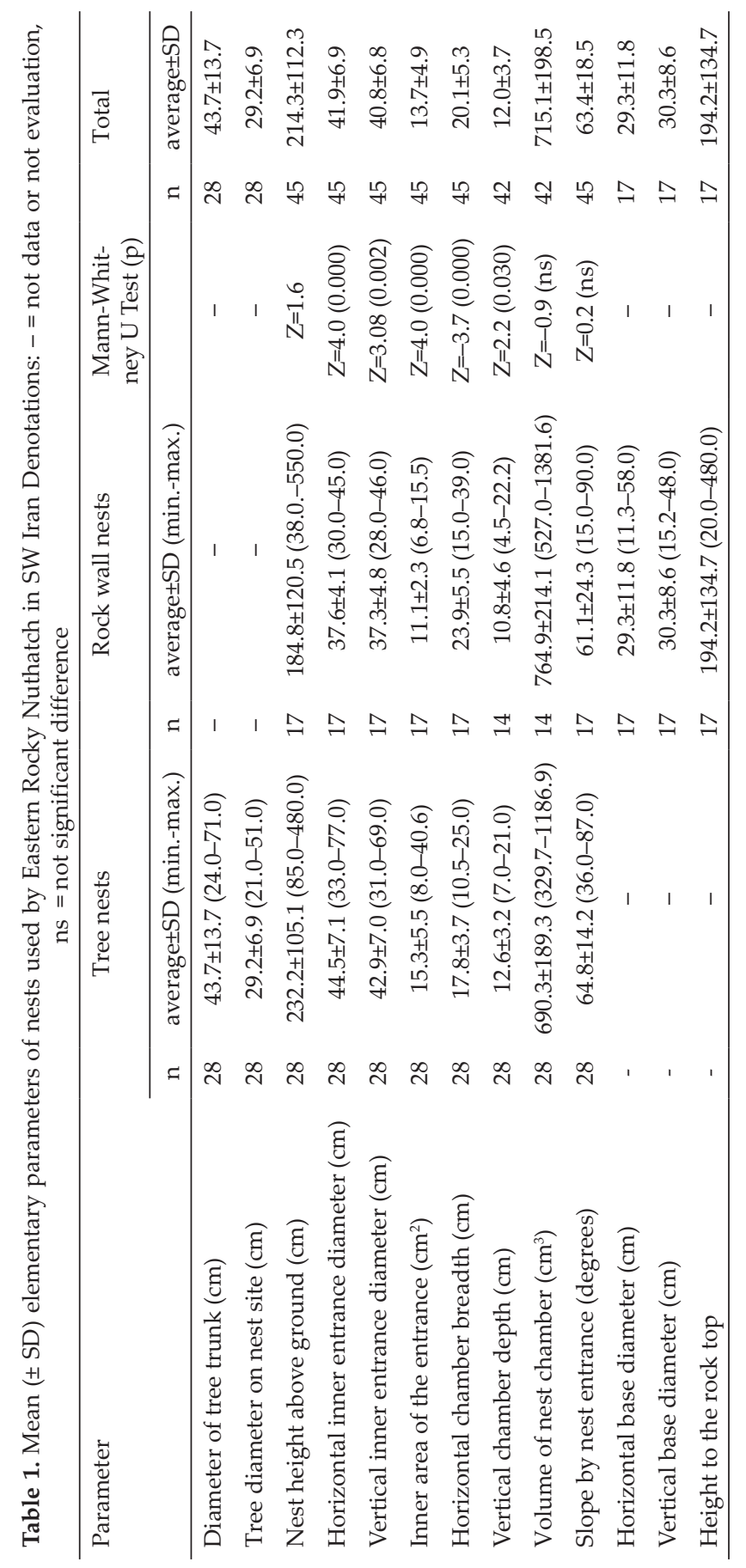


Table 2. Mean $( \pm S D)$ parameters of the main species of trees used for nesting by the Eastern Rock Nuthatch in SW Iran. For all studied parameters, no significant differences were found (for all cases Mann-Whitney U Test $<1.52, \mathrm{p}>0.128$ )

\begin{tabular}{lcc}
\hline Parameter & $\begin{array}{c}\text { Fraxinus angustifolia } \\
(\mathrm{n}=7)\end{array}$ & $\begin{array}{c}\text { Pistacia atlantica } \\
(\mathrm{n}=20)\end{array}$ \\
\hline Diameter of tree trunk $(\mathrm{cm})$ & $41.8 \pm 7.4$ & $44.3 \pm 15.7$ \\
Tree diameter on nest site $(\mathrm{cm})$ & $31.9 \pm 8.1$ & $27.2 \pm 4.1$ \\
Nest height above ground $(\mathrm{cm})$ & $239.7 \pm 90.4$ & $236.9 \pm 109.3$ \\
Horizontal inner entrance dimeter $(\mathrm{cm})$ & $43.4 \pm 2.4$ & $45.0 \pm 8.3$ \\
Vertical inner entrance dimeter $(\mathrm{cm})$ & $43.4 \pm 5.5$ & $42.8 \pm 7.8$ \\
Inner area of the entrance $\left(\mathrm{cm}^{2}\right)$ & $14.9 \pm 2.4$ & $15.6 \pm 6.4$ \\
Horizontal chamber breadth $(\mathrm{cm})$ & $16.9 \pm 3.5$ & $17.8 \pm 3.7$ \\
Vertical chamber depth $\left(\mathrm{cm}^{2}\right)$ & $14.0 \pm 4.5$ & $12.3 \pm 2.3$ \\
Volume of nest chamber $\left(\mathrm{cm}^{3}\right)$ & $738.2 \pm 254.5$ & $681.6 \pm 167.9$ \\
Slope by nest entrance $(\mathrm{degrees})$ & $70.4 \pm 11.6$ & $62.1 \pm 14.6$ \\
\hline
\end{tabular}

vertical and horizontal diameter of the nest chambers differed between these two nest type categories, chamber volumes did not differ statistically (Table 1). The horizontal and vertical base diameters of the rocky nests were very similar (Mann-Whitney $\mathrm{U}$ Test $\mathrm{Z}=-0.63$, ns). We did not find any statistical correlations between nest height, inner vertical, or horizontal diameters or the

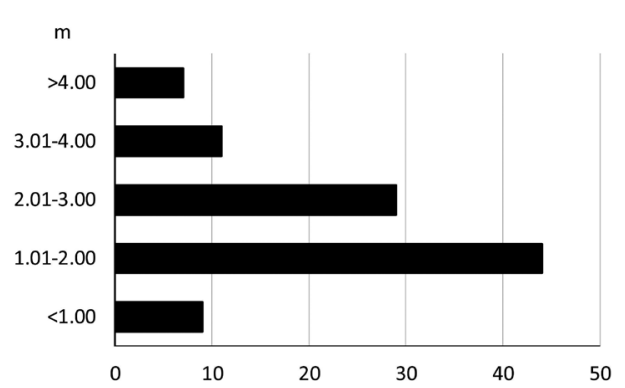

Fig. 4. Percentage distribution of the Eastern Rocky Nuthatch nests height above the ground $(\mathrm{n}=45)$

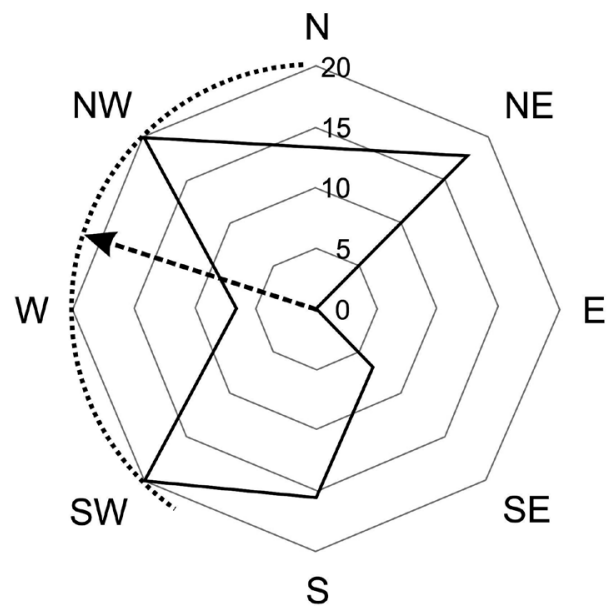

Fig. 5. Share of entrance orientations of Eastern Rock Nuthatch nests (percentage evaluation is given, $\mathrm{n}=45$ ). The mean nest entrance direction (dashed arrow) with 95\% confidence interval (dotted line) is presented 
entrance area of nests (Spearman's rank correlation, respectively: $\mathrm{r}=0.087, \mathrm{r}=$ $0.009, r=0.042$, for all cases $n=45$ ). The nest entrances were oriented mainly north-south rather than east-west (Fig. 5). Nests were mostly oriented northwest-southeast (by 20\%, $\mathrm{n}=45$ ) and northeast, south and north (respectively $17.8 \%, 15.6 \%, 13.3 \%$ ). Only three nests were oriented west or northeast (Fig. 5). The results of the circular statistics reveal that the nest entrance distribution was uniform (Rayleigh's $\mathrm{R}$ test, $\mathrm{p}=0.21$ ). The mean entrance direction was to the west (average of 278 degrees with 95\% confidence intervals 216-357 degrees, Fig. 5).

\section{DISCUSSION}

The ERN breeding pair density in the study area was slightly higher than that noted in Turkmenistan (5.3 breeding pairs per 100 ha, Rustamov 1958) and Tajikistan (3.3-4.0 breeding pairs/100 ha, AbDusalyamov 1973). In this latter region, one breeding pair occupied an area of about 25-30 ha (ABDusALYAMov 1973), implying that the birds there use a roughly circular area with a 280-310 m radius around the nest. By contrast, our ERN population showed half of this average distance between nests (i.e. the approximate radius of their territory size), which we estimated at $69 \mathrm{~m}$.

Our study shows that ERN may inhabit miscellaneous sites. In natural temperate forests in southwestern Iran, this species most frequently used tree holes, and over $60 \%$ of ERN nests were located in abandoned woodpecker holes. This is consistent with findings from other forested regions, where woodpecker holes are commonly used by secondary-hole nesters, including nuthatches (WesoŁowski 1989, Li \& Martin 1991, Pravosudov 1993). The Eurasian Nuthatch nests in trees (in habitats without nest boxes), but the proportion of nests located in old woodpecker holes ranged in studies from 32\% to 83\% (Pravosudov 1993, Wesolowski \& Rowiński 2004). The proportion of woodpecker holes used by nuthatches also depends on the availability of particular types of nest sites, e.g. natural holes, crevices or artificial nest placements like nesting boxes (e.g. WesoŁowski \& Rowiński 2004, AlbayraK \& ERDOĞAN 2005). Additionally, the ERN builds its own nests in mountain habitats. Its nest construction is very similar to that of the Western Rock Nuthatch. The gourd-like shape of the nest of these species is made from mud with an entrance at the top, and in treeless habitats is located below rocks, in bridges, and rarely in gaps in stones and rocks. Both species nest in cliffs, rocky walls, narrow valleys, and stony places and are also able to use buildings and walls (Cramp \& SNOw 2000, Harrap 2019). Similar nest placements were used by the ERN in the study area and other regions (Paludan 1959, Cramp \& Snow 2000, Naurouzi 2010). However, in regions where both species occur together, they probably avoid each other (Harrap 2019). Gener- 
ally, the Western Rock nuthatch lives at lower altitudes (range from 900 up to about 1,500 $\mathrm{m}$ a.s.l.) in comparison to the ERN, which is found at altitudes up to 3,300 $\mathrm{m}$ a.s.l. (HARrap 2019). We found ERN nests at high elevations, ranging from 2,013-2,833 $\mathrm{m}$ a.s.l. This is probably the way these two species avoid competition in the co-occurring area, which may positively influence their breeding success (e.g. Ingold 1989, Wesolowski \& StawarczyK 1991, Ingold 1994, Strubbe \& Matthysem 2009).

Nest placement plays a crucial role in avian anti-predator strategies (e.g. EgGers et al. 2006). Some studies have shown that more highly placed nests are safer in comparison to lower nests (Nilsson 1984, Gutzwiller \& ANDERson 1987, Li \& MARTIN 1991); if nests are not placed high enough, there is a greater probability of the nest being destroyed by other animals or people (authors' unpublished data). However, the nests of the studied ERNs were located at low heights and about $80 \%$ were situated only up to $3 \mathrm{~m}$ above the ground. This is extremely low in comparison to other smaller nuthatch species, such as Krüper's Nuthatch or the Eurasian Nuthatch, which respectively nest at 12 and 6-14 meters above the ground (Pravosudov 1993, WesoŁowsKi \& Rowiński 2004, Albayrak \& ERdoĞAn 2005). Additionally, the trees used by ERNs were $\sim 20 \mathrm{~cm}$ smaller in trunk diameter than trees inhabited by the Eurasian Nuthatch (based on tree trunk measurements at the height of 65 cm reported in WesoŁowski \& Rowiński 2004). Even though each species has different habitat requirements, these data suggest that nuthatches (like woodpeckers) also selected nest locations high in tree stands that have trees with thicker trunks as well as greater heights (WESOŁOWsKi \& RowińsKi 2004, Kosiński et al. 2006, Michalczuk \& Michalczuk 2016). We, therefore, assume that in our study area, the ERN was able to inhabit only lower-placed tree nests. Moreover, the ERN nested approximately half a meter lower in rocky sites compared to tree sites. However, in these cases, the birds chose locations in the upper half of the cliff, which potentially could be less accessible to predators.

Nuthatches form the bottom and chamber dimensions of their nest holes using materials such as wool, paper, bark and various plant materials. They are able to shape properly sized hole entrances by plastering them with mud (Cramp \& Snow 2000, Harrap 2019). In this way, these species may control nest access by predators and increase the probability of successful breeding attempts (WesoŁowski \& Rowiński 2004). The larger hole entrance size we noted in tree nests suggests that ERN nests should be more exposed to predation risk. However, the nuthatches were able to protect broods better in nests that were higher in trees than in the rocky sites. Confirming this was the observation that some broods located in rocks were destroyed by snakes (authors' unpublished data). These data suggest that this nest placement is more susceptible to predation than nests located in trees. For this reason, we in- 
fer that ERNs create smaller hole entrances in rocky nests to more effectively protect broods from predation. However, it should be noted that smaller tree nests are limited by the size of the trees. These holes, which were excavated and abandoned by woodpeckers, do not allow ERNs to build larger nest constructions. As a result, to avoid predation and breeding losses, ERNs made tree nests with deeper chambers in comparison to the rocky ones.

Our studies show that most nest entrances were oriented north-south, with the mean direction to the west. A higher frequency of southern directions was exhibited by the Eurasian Nuthatch (WesoŁowski \& Rowiński 2004) and Krüper's Nuthatch (AlbayraK \& ERDOGAN 2005). The ERN did not orient any nests to the east, suggesting that the ERN avoids the cold eastern winds that occur in this area (Meteorological Organization of the Islamic Republic of Iran 2017). Similar dependencies in nest preferences were found in other studies (e.g. Rodriguez et al. 2011, Bouvier et al. 2014, Kiss et al. 2017). It is likely that this species uses the warmth of western sunlight to aid in the thermoregulation of eggs and nestlings, which may influence the reproductive success (e.g. Austin 1974, Hooge et al. 1999, Burton 2006). Conversely, sap saturation and precipitation may have negative impacts on breeding success, reducing the reproductive success of woodpeckers (PASINELLI 2001) and secondary hole nesters (WesoŁowski et al. 2002). Probably, for this reason, nests exposed to rain or moisture were not reused by ERNs the following year (authors' unpubl. data).

Our study suggests that the availability of tree holes made by woodpeckers may play a very important role in the breeding performance and occurrence of the ERN in montane temperate forests. It also confirms that this secondary cavity-nesting species is sensitive to cavity availability in this habitat (WesoŁowski 1989, Camprodon et al. 2008, Cоскіe et al. 2011). To protect this species, we should focus on saving trees with woodpecker holes. Nevertheless, more ecologically flexible species (including other nuthatches, e.g. Krüper's or the Eurasian Nuthatch) can use artificial nest cavities, such as nest boxes (AlbayraK \& ErdoĞan 2005, Maicas et al. 2012, Camprodon et al. 2008). However, sometimes, not all of them can use nest boxes readily because they are mounted in tree stands only for breeding performance studies (e.g. AlbayraK \& ErdoĞan 2005, Maicas et al. 2012). Studies show that nuthatches only sporadically breed in nest boxes (Albayrak \& ErdoĞan 2005, Maicas et al. 2012) because the nest selection of birds could be dependent on many habitat features (e.g. Loman 2006). This study has also shown that the ERN occasionally nests near human settlements, inhabiting building or wall cavities. Thus it seems that the ERN can use artificial, human-made nest sites. For this reason, we suggest that future research on this species investigate its use of nest boxes and related breeding success via experimental field studies. 
Acknowledgements - We appreciate the improvements in English usage made by Nicola Arcilla through the Association of Field Ornithologists' program of editorial assistance. We would like to thank the anonymous reviewers for their suggestions and comments.

\section{REFERENCES}

Abdusalyamov, I. A. (1973): Fauna Tadzhixkoj SSR. Tom XIX. Chast I. Pticy. In: AbdusalyaMov, I. A. Fauna Tajik SSR. Volume XIX. Part I. Birds., Dushanbe.

Albayrak, T., Bairlein, F. \& ErdoĞan, A. (2010): Habitat parameters and breeding density of Kruper's Nuthatch Sitta krueperi Pelzeln in southern Turkey. - Polish Journal of Ecology 58: 545-552.

Albayrak, T., Besnard, A. \& ErdoĞan, A. (2011): Morphometric variation and population relationships of Kruper's Nuthatch (Sitta krueperi) in Turkey. - Wilson Journal of Ornithology 123: 734-740. https://doi.org/10.1676/11-036.1

AlbayraK, T. \& ErdoĞAn, A. (2005): Breeding ecology of Krüper's Nuthatch (Sitta krueperi) near Antalya, Turkey. - Israel Journal of Zoology 51: 309-314.

Albayrak, T. \& ErdoĞan, A. (2018): Distribution, density, and important hotspots of Krüper's Nuthatch Sitta krueperi in Turkey and Lesvos Island, Greece. - Turkish Journal of Zoology 42: 578-584. https://doi.org/10.3906/zoo-1706-7

Ar, A., Barnea, A., Yom-Tov, Y. \& Mersten-Katz, C. (2004): Woodpecker cavity aeration: a predictive model. - Respiratory Physiology E Neurobiology 144: 237-249. https://doi. org/10.1016/j.resp.2004.04.019

Ar, A. \& Piontkewitz, Y. (1992): Nest ventilation explains gas composition in the nestchamber of the European bee-eater. - Respiration Physiology 87: 407-418. https://doi. org/10.1016/0034-5687(92)90021-N

Austin, G. T. (1974): Nesting success of the Cactus Wren in relation to nest orientation. Condor 76: 216-217. https://doi.org/10.2307/1366737

Batschelet, E. (1981): Circular statistics in biology. - Academic Press, London, 371 pp.

BirdLife International (2016): Sitta tephronota. The IUCN Red List of threatened species 2016. http://dx.doi.org/10.2305/IUCN.UK.2016-3.RLTS.T22711211A87827898.en, [accessed 2018.05.06]

Bouvier, J. C., Muller, I., GénARd, M., Lescourret, F. \& Lavigne, C. (2014): Nest-site and landscape characteristics affect the distribution of breeding pairs of European Rollers Coracias garullus in an agricultural area of southeastern France. - Acta Ornitholologica 49: 23-32. https://doi.org/10.3161/000164514X682869

Brawn, J. D. \& BAldA, R. P. (1988): Population biology of cavity nesters in northern Arizona: do nest sites limit breeding densities? - Condor 90: 61-71. https://doi. org/10.2307/1368434

Burton, N. H. K. (2006): Nest orientation and hatching success in the Tree Pipit Anthus trivialis. - Journal of Avian Biology 37: 312-317. https://doi.org/10.1111/j.2006.09088857.03822.x

Camprodon, J., Salvanya, J. \& Soler-Zurita J. (2008): The abundance and suitability of tree cavities and their impact on hole-nesting bird populations in beech forest of NE Iberian Peninsula. - Acta Ornithologica 43(1): 17-31. https://doi.org/10.3161/000164508X345293 
Cockie, K., Martin, K. \& Wiebe, K. (2011): Selection of nest trees by cavity-nesting birds in the Neotropical Atlantic Forest. - Biotropica 43: 228-236 https://doi.org/10.1111/j.17447429.2010.00661.x

Cramp, S. \& Snow, D. (eds) (2000): The complete birds of the Western Palearctic. - CD-ROM edition, Oxford University Press, Oxford.

Eggers, S., Griesser, M., Nystrand, M. \& Ekman, J. (2006): Predation risk induces changes in nest-site selection and clutch size in the Siberian Jay. - Proceedings of the Royal Society 273: 701-706. https://doi.org/10.1098/rspb.2005.3373

Facemire, C. F., Facemire, M. E. \& Facemire, M. C. (1990): Wind as a factor in the orientation of entrances of Cactus Wren nests. - Condor 92: 1073-1075. https://doi. org $/ 10.2307 / 1368745$

Ghalambor, C. K. \& Martin, T. E. (2002): Comparative manipulation of predation risk in incubating birds reveals variability in the plasticity of responses. - Behavioral Ecology 13: 101-108. https://doi.org/10.1093/beheco/13.1.101

González-Varo, J.P., López-Bao, J. V. \& Guitián, J. (2008): Presence and abundance of the Eurasian nuthatch Sitta europaea in relation to the size, isolation and the intensity of management of chestnut woodlands in the NW Iberian Peninsula. - Landscape Ecology 23: 79-89. https://doi.org/10.1007/s10980-007-9166-7

Gutzwiller, K. J. \& Anderson, S. H. (1987): Multiscale associations between cavity-nesting birds and features of Wyoming Streamside Woodlands. - Condor 89: 534-548. https:// doi.org/10.2307/1368643

Hammer, Ø., Harper, D. A. T. \& Ryan, P. D. (2001): PAST: Paleontological statistics software package for education and data analysis. - Palaeontologia Electronica 4: 9 pp.

Harrap, S. (ed.) (1996): Tits, nuthatches and treecreepers. - Helm C., A \& C Black, London.

Harrap, S. (2019): Eastern Rock Nuthatch (Sitta tephronota). In: Del Hoyo, J., Elliott, A., Sargatal, J., Christie, D. A. \& De Juana, E. (eds): Handbook of the birds of the world alive. - Lynx Edicions, Barcelona. [retrieved from https://www.hbw.com/node/59934 on 4 February 2019]

Hooge, P. N., Stanback, M. T. \& Koenig, W. D. (1999): Nest-site selection in the Acorn Woodpecker. - Auk 116: 45-54. https://doi.org/10.2307/4089452

INGOLD, D. J. (1989): Nesting phenology and competition for nest sites among Red-headed and Red-bellied Woodpeckers and European Starling. - Auk 106: 209-217.

INGOLD, D. J. (1994): Influence of nest-site competition between European starlings and woodpeckers. - Wilson Bulletin 106: 227-241.

Kiss, O., Toкорy, B., Ludnai, T. \& Moskát, C. (2017): The effectiveness of nest-box supplementation for the conservation of European Rollers (Coracias garrulus). - Acta Zoologica Academiae Scientiarum Hungaricae 63: 123-135. https://doi.org/10.17109/ AZH.63.1.123.2017

Kosiński, Z., Ksit, P. \& Winiecki, A. (2006): Nest sites of Great Spotted Woodpeckers Dendrocopos major and Middle Spotted Woodpeckers Dendrocopos medius in near-natural and managed riverine forests. - Acta Ornithologica 41: 21-32. https://doi. org/10.3161/068.041.0108

Landler, L., Ruxton, G. D. \& Malkemper, E. P (2018): Circular data in biology: advice for effectively implementing statistical procedures. - Behavioral Ecology and Sociobiology 72: 128. https://doi.org/10.1007/s00265-018-2538-y

Li, P. J. \& Martin, T. E. (1991): Nest-site selection and nesting success of cavity-nesting birds in high elevation forest drainages. - Auk 108: 405-418. 
LöHrL, H. (1987): Versuche zur Wahl der Bruthöhle und Nisthöhe am Baum durch den Kleiber (Sitta europaea). - Ecology of Birds 9: 65-68.

Loman, J. (2006): Does nest site availability limit the density of hole nesting birds in small woodland patches? - Web Ecology 6: 37-43. https://doi.org/10.5194/we-6-37-2006

Maícas, R., Bonillo, J. C. \& Haeger, J. H. (2012): Temporal and spatial factors shaping reproductive performance in a Mediterranean population of the Eurasian Nuthatch Sitta europaea. - Ardeola 59: 267-277. https://doi.org/10.13157/arla.59.2.2012.267

Matthysen, E. (1998): The Nuthatches. - Poyser, London, 315 pp.

Maziarz, M., WesoŁowski, T., Hebda, G., Cholewa, M. \& Broughton, R. K. (2016): Breeding success of the Great Tit Parus major in relation to attributes of natural nest cavities in a primeval forest. - Journal of Ornithology 157: 343-354. https://doi.org/10.1007/ s10336-015-1294-2

Menon, S., Islam, Z. \& Peterson, A. (2009): Projected climate change effects on nuthatch distribution and diversity across Asia. - The Raffles Bulletin of Zoology 57: 569-575.

Meteorological Organization of Islamic Republic of Iran (2017): www.irimo.ir [access ed 2017.05.06]

Michalczuk, J. \& Michalczuk, M. (2016): Nesting preferences of Syrian Woodpeckers Dendrocopos syriacus in the agricultural landscape of SE Poland. - Acta Ornithologica 51: 71-81. https://doi.org/10.3161/00016454AO2016.51.1.006

Moulaï, R., Bouchareb, A., Gheribi, A. \& Bougaham, A. F. (2017): Statut de la population et biologie de la reproduction de la Sittelle Kabyle Sitta ledanti dans la forêt de Guerrouch (Algérie). - Alauda 85: 101-107.

MugaAs, J. N. \& Templeton, J. R. (1970): Thermoregulation in the Red-breasted Nuthatch (Sitta canadensis). - Condor 72: 125-132. https://doi.org/10.2307/1366621

Naurouzi, A. (2010): Ecology of Eastern Rock Nuthatch (Sitta tephronota) Khoshyeylagh Wildlife Refuge in NE Iran. - MSc thesis, Azad University, Tehran, 77 pp.

Nilsson, S. G. (1984): The evolution of nest-site selection among hole-nesting birds: the importance of nest predation and competition. - Ornis Scandinavica 15: 167-175. https:// doi.org/10.2307/3675958

Norris, A. R. \& Martin, K. (2012). Red-breasted nuthatches (Sitta canadensis) increase cavity excavation in response to a mountain pine beetle (Dendroctonus ponderosae) outbreak. - Ecoscience 19: 308-315. https://doi.org/10.2980/19-4-3519

Paludan, K. (1959): On the birds of Afghanistan. - Bianco Lunos Boctrykkeri A/S, Kopenhaga, 332 pp. https://doi.org/10.24157/ARC_12637

Pasinelli, G. (2001): Breeding performance of the Middle Spotted Woodpecker Dendrocopos medius in relation to weather and territory quality. - Ardea 89: 353-361.

Pasqued, E., Barker, F. K., Martens, J., Tillier, A., Cruaud, C. \& Cibois, A. (2014): Evolution within the nuthatches (Sittidae: Aves, Passeriformes): molecular phylogeny, biogeography, and ecological perspectives. - Journal of Ornithology 155: 755-765. https:// doi.org/10.1007/s10336-014-1063-7

Porter, R. \& Spinall, S. (2010): Helm field guides. Birds of the Middle East. 2nd ed. - Christopher Helm, London, 384 pp.

Pravosudov, V. V. (1993): Breeding biology of the Eurasian Nuthatch in Northeastern Siberia. - Wilson Bulletin 105(3): 475-482.

Remm, J., Lthmus, A. \& Remm, K. (2006): Tree cavities in riverine forests: What determines their occurrence and use by holenesting passerines? - Forest Ecology and Management 221: 267-277. https://doi.org/10.1016/j.foreco.2005.10.015 
Rodriguez, J., Aviles, J. M. \& Parejo, D. (2011): The value of nest boxes in the conservation of Eurasian Rollers Coracias garrulous in southern Spain. - Ibis 153: 735-745. https:// doi.org/10.1111/j.1474-919X.2011.01161.x

Rustamov, A. K., Dementyev, G. P. \& Tashliev, A. O. (1958): Pticy Turkmenistana. - Izdatelstvo Akademii Nauk Turkmenskoj SSR, Aschabad.

Scott, D. A., Moravvej-Hamadani, H. \& Adhami-Mirhosseyni, A. (1975): The birds of Iran. - Department of the Environment, Tehran, 411 pp. [in Persian]

Serrano-Davies, E., Barrientos, R. \& Sanz, J. J. (2017): The role of nest-box density and placement on occupation rates and breeding performance: a case study with Eurasian Blue Tits. - Ornis Fennica 94: 21-32.

Strubbe, D. \& Matthysem, E. (2009): Experimental evidence for nest-site competition between invasive Ring-necked Parakeets Psittacula krameri and native nuthatches Sitta europaea. - Biological Conservation 142: 1588-1594. https://doi.org/10.1016/j.biocon.2009.02.026

Thibault, J. C., Hacquemand, D., Moneglia, P., Pellegrini, H., Prodon, R., Recorbet, B., Seguin, J. F. \& Villard, P. (2011): Distribution and population size of the Corsican Nuthatch Sitta whiteheadi. - Bird Conservation International 21: 199-206. https://doi. org/10.1017/S0959270910000468

Thibault, J. C. \& Villard, P. (2005): Reproductive ecology of the Corsican Nuthatch Sitta whiteheadi. - Bird Study 52: 282-288. https://doi.org/10.1080/00063650509461401

VAurie, C. (1950): Notes on some Asiatic nuthatches and creepers. - American Museum Novitates 1472: 1-39.

WesoŁowski, T. (1989): Nest-sites of hole-nesters in a primeval temperate forest (Białowieża National Park, Poland). - Acta Ornithologica 25: 321-351.

WesoŁowski, T., Czeszczewik, D., Rowiński, P. \& Walankiewicz ,W. (2002): Nest soaking in natural holes - a serious cause of breeding failure? - Ornis Fennica 79: 132-138.

WesoŁowski, T. \& Rowinski, P. (2004): Breeding behaviour of Nuthatch Sitta europaea in relation to natural hole attributes in a primeval forest. - Bird Study 51: 143-155. https://doi.org/10.1080/00063650409461346

WesoŁowski, T. \& STAWARCZYK, T. (1991): Survival and population dynamics of nuthatches Sitta europaea breeding in natural cavities in a primeval temperate forest. - Ornis Scandinavica 22: 143-154. https://doi.org/10.2307/3676545

www.jrsoftworx.com [accessed 2015.04.09]

ZielińsKi J. (2011): The influence of nest placement on breeding success of the Blackcap (Sylvia atricapilla L.) in two different forest habitats. - Polish Journal of Ecology 59: 391-401.

Received February 7, 2019, accepted November 14, 2019, published March 6, 2020 